\title{
Risk factors for comorbidities in Czech psoriatic patients: Results of a hospital-based case-control study
}

\author{
Jana Votrubovaa , Katerina Juzlovaa , Zdenek Smerhovsky ${ }^{b}$, Jorga Fialova ${ }^{a}$, Dana Gopfertovab ${ }^{b}$ Nadezda Vojackovaa \\ Jana Hercogova ${ }^{a}$
}

\begin{abstract}
Background. Psoriasis is now known to be associated with multiple other diseases/comorbidities - including the metabolic syndrome, atherosclerosis and gastrointestinal diseases which are all significantly higher in psoriasis patients. Research results however are highly variable and the conclusions are ambiguous. As no similar study has been performed to date in Czech psoriatic patients, this study aimed at identifying risk factors and early stages of selected diseases/comorbidities in the patients.

Methods and Results. The study was designed as a hospital-based case-control study. 131 patients with chronic plaque psoriasis formed the cases and 267 patients with other skin disorders formed the controls. A comparison was made of basic demographic and anthropometric indicators, metabolic parameters, the presence of specific antibodies (ASCA, AEP, p-ANCA, AGC, EMA, ARA, t-TG, AGA) and non-specific signs of gastrointestinal diseases. The chi squared, MWU tests and binary logistical model were used to evaluate the data. The results showed significant differences $(P<0.05)$ for the following parameters: blood pressure, waist circumference, weight, BMI values, leucocytes values, HDL cholesterol level, glycemia and gliadine antibody IgA level. All differences were to the detriment of psoriasis patients. In the binary logistical model the following parameters were associated with psoriasis: diastolic blood pressure, leucocyte value and glycemia. For all variables included in the logistical model $P \leq 0.001$.

Conclusions. The results were coherent and consistent with existing data. They indicate that psoriasis is interconnected with hypertension, higher BMI and a decreased level of HDL cholesterol. These parameters have been clearly demonstrated as risk factors for the development of cardiovascular diseases. Higher levels of gliadine IgA antibodies are one of the diagnostic markers of celiac disease. Higher values of leukocytes may be interpreted as a nonspecific indicator of gastrointestinal inflammatory diseases. The associations between psoriasis and diastolic blood pressure, $\mathrm{BMI}$ value and glycemia are statistically significant in the binary logistic regression model. Care for psoriatic patients should focus especially on secondary prevention of predisposing diseases.
\end{abstract}

Key words: psoriasis, co-morbidities, risk factors, hospital-based case-control study

Received: February 26, 2013; Accepted: August 22, 2013; Available online: September 27, 2013 http://dx.doi.org/10.5507/bp.2013.062

\footnotetext{
${ }^{a}$ Department of Dermatovenereology, $2^{\text {nd }}$ Faculty of Medicine, Charles University in Prague, Prague, Czech Republic ${ }^{b}$ Department of Epidemiology, $2^{\text {nd }}$ Faculty of Medicine, Charles University in Prague, Prague Corresponding author: Jana Votrubova, e-mail: jana-votrubova@seznam.cz
}

\section{INTRODUCTION}

Psoriasis is a chronic inflammatory skin disease, the prevalence of which is around $1.5 \%$ to $4.7 \%$ in Europe and in the USA. Some publications show that patients with psoriasis have a higher risk of developing systemic comorbidities such as metabolic syndrome, diabetes mellitus and cardiovascular disease ${ }^{1-4}$. In contrast to this statement, other authors found no association between severe psoriasis and obesity or between obesity and cardiovascular mortality in their studies 5 . Recent studies show that patients with psoriasis have an increased risk of insulin resistance, obesity, dyslipidemia and hypertension. Obesity has been identified as an independent risk factor for the development of psoriasis. Psoriasis is associated with diabetes, coronary artery disease as well as with an increased risk of myocardial infarction. A possible reason for the coincidence of metabolic syndrome and psoriasis is that they share similar pathological changes such as chronic inflammation, angiogenesis and oxidative stress $^{6,7}$. Higher mortality due to cardiovascular disease was observed in patients with the severe form of psoria$\mathrm{sis}^{8,9}$. The presence of psoriasis in the past medical history of a patient is considered to be one of independent risk factors of atherosclerosis ${ }^{10}$.

A study of the Swedish and Finnish populations confirms the connection between psoriasis and inflammatory bowel diseases (IBDs), in which both have been associated with the IL23-R gene. So far there is no proven connection between celiac disease and psoriasis ${ }^{11}$. There is a possible association between celiac disease and psoriasis as seen by the fact that a gluten-free diet leads to a clear improvement and disappearance of psoriatic skin lesions in some patients ${ }^{12}$. Associated diseases significantly impair the quality of life of patients suffering from psoriasis and contribute to the increased morbidity and mortality 
of these patients ${ }^{13,14}$. Based on the clinical experience and results of studies, we expected a higher prevalence of the metabolic syndrome and inflammatory bowel diseases in patients with chronic stationary form of psoriasis than in the general population. The aim of our project was to test the hypothesis that the prevalence of the metabolic syndrome and inflammatory gastrointestinal diseases is higher in patients with chronic stationary form of psoriasis than in the general population.

\section{MATERIALS AND METHODS}

The study was designed as a hospital-based case-control study. Patients with chronic plaque psoriasis were enrolled as cases. The control group, selected on the basis of a ratio of 1:2, was composed of patients with other skin diseases who complied with the same restrictive criteria used in cases. A comparison of basic demographic and anthropometric indicators, metabolic parameters, the presence of specific antibodies (ASCA, AEP, p-ANCA, AGC, EMA, ARA, t-TG, AGA) and non-specific signs of gastrointestinal diseases were carried out between cases and controls. The statistical significance of differences between cases and controls was tested by means of Chiquadrat test or Mann-Whitney U test. We used the binary logistic regression to multivariate modelling of the association between psoriasis and the aforementioned indicators.

131 cases and 267 controls were included in the study. There were statistically significant differences between cases and controls with regard to a few important parameters. We found significant differences $(P<0.05)$ for the following parameters: blood pressure, waist circumference, weight, BMI values, leucocytes values, HDL cholesterol level, glycemia and gliadine antibody IgA level. All differences were to the detriment of psoriasis patients of. In the binary logistical model the following parameters were associated with psoriasis: diastolic blood pressure, leucocytes value and glycemia (for all the parameters included in the logistical model $P \leq 0.001$ ).

\section{Study population}

Patients suffering from chronic plaque psoriasis were enrolled in this study. The controls were selected by means of frequency matching with a ratio of 2 controls for 1 case. They were selected among other dermatology patients not suffering from psoriasis. The cases and controls were subject to the same selection criteria. Al the persons suffering from chronic and autoimmune diseases, hypertension, diabetes mellitus, persons with centripetal obesity (men with a waist circumference greater than 102 $\mathrm{cm}$ and women greater than $88 \mathrm{~cm}$ ) and patients with apparent signs for tested risk factors and diseases were excluded.

\section{Scope of medical examination}

In each study subject we determine the following:

- age, sex

- smoking

- waist circumference $(\mathrm{cm})$, weight $(\mathrm{kg})$, height $(\mathrm{m})$, body mass index (BMI)

- blood pressure $(\mathrm{mmHg})$, glycemia $(\mathrm{mmol} / \mathrm{L})$

- blood lipids: total cholesterol (mmol/L), low-density lipoprotein cholesterol (LDL), high density lipoprotein cholesterol (HDL), triacylglycerol (TAG)

- ASCA - Anti- Saccharomyces cerevisiae antibodies ( Crohn's disease)

- AEP - Anti- acinar cytoplasmic granule pancreatic antibodies (Crohn's disease)

- p-ANCA - perinuclear antibodies to neutrophil granulocyte cytoplasm component (Ulcerative colitis)

- AGC-Anti - goblet cell antibodies (markers for inflammatory bowel disease)

- EMA - Anti - endomysium antibodies (celiac disease)

- ARA - Anti - reticuline antibodies (celiac disease)

- t-TG - Anti - transglutaminase antibodies IgA, IgG (celiac disease - $\mathrm{U} / \mathrm{mL}$ )

- AGA - Anti - gliadine antibodies IgA, IgG (celiac disease- $\mathrm{U} / \mathrm{mL}$ )

- nonspecific signs of gastrointestinal diseases

o blood count (erythrocytes x1012/L, leucocytes X 109/L, thrombocytes x 109/L)

o haemoglobin $(\mathrm{g} / \mathrm{L})$

o iron level $(\mu \mathrm{mol} / \mathrm{L})$

o total serum protein level $(\mathrm{g} / \mathrm{L})$

o C-reactive protein level (CRP - mg/L)

\section{Statistical analysis}

Due to asymmetric distribution of most of the studied variables, the differences between cases and controls were tested by means of Mann-Whitney U test at bivariate level. Simultaneous effects of the studied variables on the occurrence of psoriasis were studied by binary logistic regression. The point estimates of odds ratios and 95\% CI describing the strength of association between independent predictors and Psoriasis are reported. Level of statistical significance in all tests was set to 0.05 .

\section{RESULTS}

Data for 131 cases and 267 controls are available. The main characteristics and the distribution of studied parameters are shown in Tables 1 and 2. Tests of statistically significant differences between cases and controls can be found in both tables.

The comparison revealed statistically significant differences for several variables (Table 1 and 2). Psoriasis cases had higher blood pressure than controls (Fig. 1), a bigger waist circumference and greater BMI (Fig. 2). The cases had a higher leucocyte count (Fig. 3) and titres gliadine IgA antibodies (Fig. 5) as well. In cases, the HDL level (Fig. 4) was significantly lower. Another difference between cases and controls was in glucose concentration 
Table 1. Distributions of studied parameters and control comparison.

\begin{tabular}{|c|c|c|c|c|c|c|c|c|}
\hline & & \multicolumn{2}{|c|}{ Status } & \multirow{2}{*}{ Total } & \multirow{2}{*}{ OR } & \multicolumn{2}{|c|}{ 95\% C.I. pro OR } & \multirow{2}{*}{ Sig. } \\
\hline & & Control & Case & & & Lower & Upper & \\
\hline \multirow[t]{2}{*}{ Gender } & Man & 136 & 81 & 217 & 1.00 & & & \\
\hline & Woman & 131 & 50 & 181 & 0.64 & 0.42 & 0.98 & 0.040 \\
\hline Total & & 267 & 131 & 398 & & & & \\
\hline \multirow{2}{*}{ ARA } & Neg. & 266 & 128 & 394 & 1.00 & & & \\
\hline & Pos. & 1 & 3 & 4 & 6.23 & 0.64 & 60.52 & 0.072 \\
\hline Total & & 267 & 131 & 398 & & & & \\
\hline \multirow[t]{2}{*}{ ASCA } & Neg. & 261 & 123 & 384 & 1.00 & & & \\
\hline & Pos. & 6 & 8 & 14 & 2.83 & 0.96 & 8.33 & 0.050 \\
\hline Total & & 267 & 131 & 398 & & & & \\
\hline \multirow[t]{2}{*}{ AEP } & Neg. & 265 & 131 & 396 & & & & \\
\hline & Pos. & 2 & 0 & 2 & - & - & - & 0.321 \\
\hline Total & & 267 & 131 & 398 & & & & \\
\hline \multirow{2}{*}{ pANCA } & Neg. & 257 & 126 & 383 & 1.00 & & & \\
\hline & Pos. & 10 & 5 & 15 & 1.02 & 0.34 & 3.05 & 0.972 \\
\hline Total & & 267 & 131 & 398 & & & & \\
\hline \multirow[t]{2}{*}{ AGCA } & Neg. & 255 & 123 & 378 & & & & \\
\hline & Pos. & 12 & 8 & 20 & 1.38 & 0.55 & 3.47 & 0.489 \\
\hline Total & & 267 & 131 & 398 & & & & \\
\hline
\end{tabular}

Table 2. Distributions of studied parameters and their comparison in controls and cases.

\begin{tabular}{|c|c|c|c|c|c|c|c|c|}
\hline Variable & Status & $\mathrm{N}$ & Minimum & Median & Mean & Maximum & Range & $\begin{array}{c}\text { Mann- } \\
\text { Whitney } \\
\text { U Test }\end{array}$ \\
\hline \multirow[t]{3}{*}{ Age (years) } & Control & 267 & 16.0 & 40.0 & 42.7 & 94.0 & 78.0 & \\
\hline & Case & 130 & 17.0 & 39.0 & 41.7 & 81.0 & 64.0 & 0.969 \\
\hline & Total & 397 & 16.0 & 39.0 & 42.4 & 94.0 & 78.0 & \\
\hline \multirow{3}{*}{$\begin{array}{l}\text { Systolic blood } \\
\text { pressure }(\mathrm{mmHg})\end{array}$} & Control & 267 & 90.0 & 120.0 & 120.4 & 170.0 & 80.0 & \\
\hline & Case & 131 & 95.0 & 130.0 & 125.8 & 160.0 & 65.0 & $<0.001$ \\
\hline & Total & 398 & 90.0 & 120.0 & 122.2 & 170.0 & 80.0 & \\
\hline \multirow{3}{*}{$\begin{array}{l}\text { Diastolic blood } \\
\text { pressure }(\mathrm{mmHg})\end{array}$} & Control & 267 & 50.0 & 80.0 & 82.6 & 120.0 & 60.0 & \\
\hline & Case & 131 & 60.0 & 80.0 & 82.6 & 120.0 & 60.0 & $<0.001$ \\
\hline & Total & 398 & 50.0 & 80.0 & 79.1 & 120.0 & 70.0 & \\
\hline \multirow{3}{*}{$\begin{array}{l}\text { Waist circumference } \\
(\mathrm{cm})\end{array}$} & Control & 267 & 60.0 & 84.0 & 83.8 & 102.0 & 42.0 & \\
\hline & Case & 131 & 64.0 & 88.0 & 88.0 & 102.0 & 38.0 & $<0.001$ \\
\hline & Total & 398 & 60.0 & 85.0 & 85.2 & 102.0 & 42.0 & \\
\hline \multirow[t]{3}{*}{ Weight (kg) } & Control & 267 & 46.0 & 74.0 & 75.3 & 126.0 & 80.0 & \\
\hline & Case & 131 & 45.0 & 79.5 & 80.7 & 152.0 & 107.0 & 0.006 \\
\hline & Total & 398 & 45.0 & 75.0 & 77.1 & 152.0 & 107.0 & \\
\hline \multirow{3}{*}{ Height (m) } & Control & 267 & 1.5 & 1.7 & 1.7 & 2.0 & 0.5 & \\
\hline & Case & 131 & 1.3 & 1.7 & 1.7 & 2.0 & 0.7 & 0.734 \\
\hline & Total & 398 & 1.3 & 1.7 & 1.7 & 2.0 & 0.7 & \\
\hline \multirow[t]{3}{*}{ BMI } & Control & 267 & 17.6 & 24.5 & 24.7 & 34.5 & 16.9 & \\
\hline & Case & 131 & 18.0 & 26.3 & 26.6 & 47.3 & 29.3 & $<0.001$ \\
\hline & Total & 398 & 17.6 & 24.8 & 25.4 & 47.3 & 29.8 & \\
\hline \multirow{3}{*}{$\begin{array}{l}\text { Leucocytes count } \\
\left(\mathrm{x} 10^{9} / \mathrm{L}\right)\end{array}$} & Control & 267 & 3.5 & 6.5 & 6.9 & 15.4 & 11.9 & \\
\hline & Case & 131 & 4.4 & 7.1 & 7.7 & 17.2 & 12.8 & $<0.001$ \\
\hline & Total & 398 & 3.5 & 6.7 & 7.2 & 17.2 & 13.7 & \\
\hline \multirow{3}{*}{$\begin{array}{l}\text { Erythrocytes count } \\
\left(\mathrm{x} 10^{12} / \mathrm{L}\right)\end{array}$} & Control & 267 & 3.3 & 4.7 & 4.7 & 6.0 & 2.7 & \\
\hline & Case & 131 & 3.2 & 4.8 & 4.8 & 5.9 & 2.8 & 0.396 \\
\hline & Total & 398 & 3.2 & 4.7 & 4.7 & 6.0 & 2.8 & \\
\hline \multirow{3}{*}{$\begin{array}{l}\text { Thrombocytes count } \\
\left(\times 10^{9} / \mathrm{L}\right)\end{array}$} & Control & 267 & 119.0 & 231.0 & 232.9 & 446.0 & 327.0 & \\
\hline & Case & 129 & 108.0 & 238.0 & 243.1 & 435.0 & 327.0 & 0.167 \\
\hline & Total & 396 & 108.0 & 232.5 & 236.2 & 446.0 & 338.0 & \\
\hline
\end{tabular}


Table 2. Distributions of studied parameters and their comparison in controls and cases. (continued)

\begin{tabular}{|c|c|c|c|c|c|c|c|c|}
\hline Variable & Status & $\mathrm{N}$ & Minimum & Median & Mean & Maximum & Range & $\begin{array}{c}\text { Mann- } \\
\text { Whitney } \\
\text { U Test }\end{array}$ \\
\hline \multirow{3}{*}{$\begin{array}{l}\text { Haemoglobin level } \\
(\mathrm{g} / \mathrm{L})\end{array}$} & Control & 267 & 99.0 & 143.0 & 144.2 & 174.0 & 75.0 & \\
\hline & Case & 131 & 101.0 & 148.0 & 146.4 & 181.0 & 80.0 & 0.093 \\
\hline & Total & 398 & 99.0 & 145.0 & 144.9 & 181.0 & 82.0 & \\
\hline \multirow{3}{*}{$\begin{array}{l}\text { Total cholesterol } \\
(\mathrm{mmol} / \mathrm{L})\end{array}$} & Control & 267 & 2.6 & 5.2 & 5.3 & 8.5 & 5.9 & \\
\hline & Case & 131 & 3.2 & 5.5 & 5.4 & 9.5 & 6.3 & 0.372 \\
\hline & Total & 398 & 2.6 & 5.3 & 5.3 & 9.5 & 7.0 & \\
\hline \multirow{3}{*}{$\begin{array}{l}\text { HDL cholesterol } \\
(\mathrm{mmol} / \mathrm{L})\end{array}$} & Control & 267 & 0.7 & 1.5 & 1.5 & 2.6 & 2.0 & \\
\hline & Case & 131 & 0.8 & 1.4 & 1.4 & 3.0 & 2.2 & 0.002 \\
\hline & Total & 398 & 0.7 & 1.4 & 1.5 & 3.0 & 2.4 & \\
\hline \multirow{3}{*}{$\begin{array}{l}\text { LDL cholesterol } \\
(\mathrm{mmol} / \mathrm{L})\end{array}$} & Control & 267 & 1.2 & 3.0 & 3.1 & 5.6 & 4.5 & \\
\hline & Case & 131 & 1.3 & 3.1 & 3.2 & 6.0 & 4.7 & 0.167 \\
\hline & Total & 398 & 1.2 & 3.0 & 3.1 & 6.0 & 4.8 & \\
\hline \multirow{3}{*}{$\begin{array}{l}\text { Triacylgycerol } \\
(\mathrm{mmol} / \mathrm{L})\end{array}$} & Control & 267 & 0.4 & 1.2 & 1.5 & 7.6 & 7.2 & \\
\hline & Case & 131 & 0.5 & 1.3 & 1.6 & 5.8 & 5.3 & 0.258 \\
\hline & Total & 398 & 0.4 & 1.3 & 1.5 & 7.6 & 7.2 & \\
\hline \multirow{3}{*}{$\begin{array}{l}\text { Glycaemia level } \\
(\mathrm{mmol} / \mathrm{L})\end{array}$} & Control & 267 & 3.1 & 4.9 & 4.9 & 9.4 & 6.3 & \\
\hline & Case & 131 & 2.8 & 4.7 & 4.8 & 7.9 & 5.1 & 0.036 \\
\hline & Total & 398 & 2.8 & 4.9 & 4.9 & 9.4 & 6.6 & \\
\hline \multirow{3}{*}{$\begin{array}{l}\text { C-reactive protein } \\
\text { level }(\mathrm{mg} / \mathrm{L})\end{array}$} & Control & 267 & 0.1 & 1.7 & 3.0 & 26.5 & 26.4 & \\
\hline & Case & 131 & 0.2 & 2.0 & 3.4 & 31.7 & 31.5 & 0.066 \\
\hline & Total & 398 & 0.1 & 1.7 & 3.1 & 31.7 & 31.6 & \\
\hline \multirow{3}{*}{$\begin{array}{l}\text { Total serum protein } \\
\text { level }(\mathrm{g} / \mathrm{L})\end{array}$} & Control & 267 & 63.0 & 75.0 & 75.1 & 88.0 & 25.0 & \\
\hline & Case & 131 & 55.0 & 74.0 & 74.3 & 86.0 & 31.0 & 0.116 \\
\hline & Total & 398 & 55.0 & 75.0 & 74.9 & 88.0 & 33.0 & \\
\hline \multirow{3}{*}{$\begin{array}{l}\text { Iron level } \\
(\mu \mathrm{mol} / \mathrm{L})\end{array}$} & Control & 267 & 3.1 & 17.7 & 17.5 & 44.8 & 41.7 & \\
\hline & Case & 131 & 2.6 & 16.7 & 17.6 & 40.1 & 37.5 & 0.925 \\
\hline & Total & 398 & 2.6 & 17.4 & 17.5 & 44.8 & 42.2 & \\
\hline \multirow{3}{*}{$\begin{array}{l}\text { Anti gliadine } \\
\text { antibodies IgA } \\
(\mathrm{U} / \mathrm{mL})\end{array}$} & Control & 267 & 0.2 & 4.0 & 4.9 & 118.0 & 117.8 & \\
\hline & Case & 131 & 0.0 & 4.3 & 5.6 & 39.5 & 39.5 & 0.039 \\
\hline & Total & 398 & 0.0 & 4.1 & 5.1 & 118.0 & 118.0 & \\
\hline \multirow{3}{*}{$\begin{array}{l}\text { Anti gliadine } \\
\text { antibodies } \mathrm{IgG} \\
(\mathrm{U} / \mathrm{mL})\end{array}$} & Control & 267 & 0.4 & 3.9 & 5.5 & 73.2 & 72.8 & \\
\hline & Case & 131 & 0.0 & 4.3 & 5.5 & 26.5 & 26.5 & 0.062 \\
\hline & Total & 398 & 0.0 & 4.1 & 5.5 & 73.2 & 73.2 & \\
\hline \multirow{3}{*}{$\begin{array}{l}\text { Anti-transglutaminase } \\
\text { antibodies IgA } \\
(\mathrm{U} / \mathrm{mL})\end{array}$} & Control & 267 & 0.4 & 2.2 & 2.0 & 9.7 & 9.3 & \\
\hline & Case & 131 & 0.0 & 2.2 & 2.1 & 8.2 & 8.2 & 0.655 \\
\hline & Total & 398 & 0.0 & 2.2 & 2.1 & 9.7 & 9.7 & \\
\hline \multirow{3}{*}{$\begin{array}{l}\text { Anti-transglutaminase } \\
\text { antibodies } \operatorname{Ig} \mathrm{A} \\
(\mathrm{U} / \mathrm{mL})\end{array}$} & Control & 267 & 0.2 & 2.0 & 2.2 & 17.9 & 17.7 & \\
\hline & Case & 131 & 0.0 & 2.1 & 2.4 & 26.3 & 26.3 & 0.164 \\
\hline & Total & 398 & 0.0 & 2.1 & 2.2 & 26.3 & 26.3 & \\
\hline
\end{tabular}

(Fig. 6). Using binary logistic regression psoriasis was positively associated with diastolic blood pressure, BMI value and leucocytosis (Table 3). The association between glucose concentration and psoriasis was negative.

\section{DISCUSSION}

The results show significant differences between psoriasis patients and control patients on several parameters: weight, waist circumference, BMI value, leukocytes, titres of gliadin and IgA antibodies, HDL cholesterol and glycemia. The association between psoriasis and diastolic blood pressure, BMI value and glycemia were statistically significant in the binary data logistic model as well.

Psoriasis therefore predisposes patients to hypertension, higher BMI values and lower HDL cholesterol. These parameters belong to the image of the metabolic syndrome and they are proven risk factors for the development of cardiovascular diseases on the basis of atherosclerosis (myocardial infarction, stroke and cardiovascular death) (ref. $\left.{ }^{15,16}\right)$. The finding that psoriasis patients had 
Table 3. Binary logistic regress in model of the association between psoriasis occurrence and studied parameters.

95\% C.I. pro OR

\begin{tabular}{lccrr} 
& OR & Lower & Upper & Sig. \\
\hline Diast. Blood pressure $(\mathrm{mmHg})$ & 1.04 & 1.02 & 1.07 & $<0.001$ \\
BMI & 1.11 & 1.04 & 1.18 & 0.001 \\
Leucocytes count $(\mathrm{x} \mathrm{10} / \mathrm{L})$ & 1.20 & 1.07 & 1.34 & 0.001 \\
Glycaemia $(\mathrm{mmol} / \mathrm{L})$ & 0.55 & 0.38 & 0.78 & 0.001 \\
Constant & 0.01 & & $<0.001$ \\
\hline
\end{tabular}

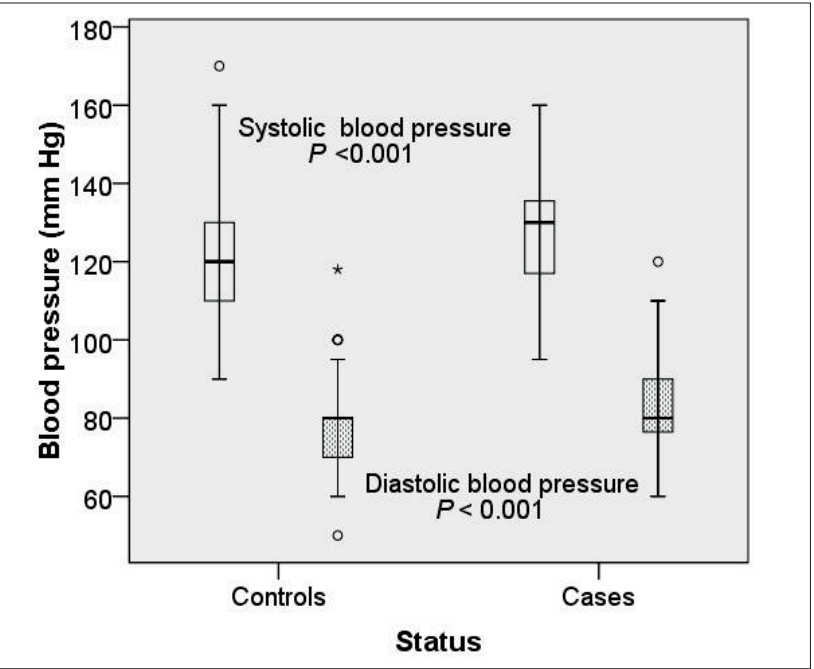

Fig. 1. Blood pressure in psoriatic patients and controls.

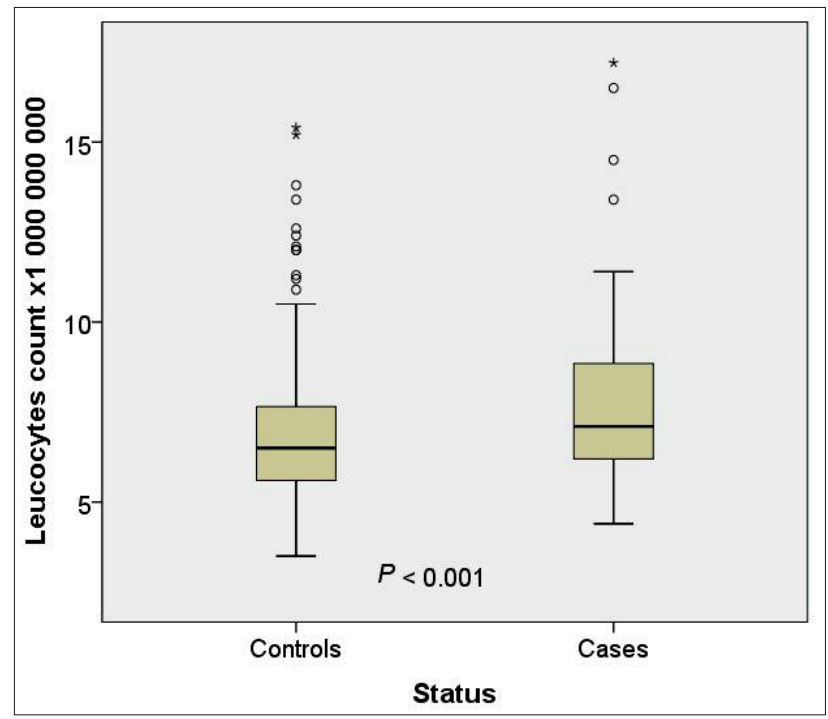

Fig. 3. Leucocytes count in psoriatic patients and controls.

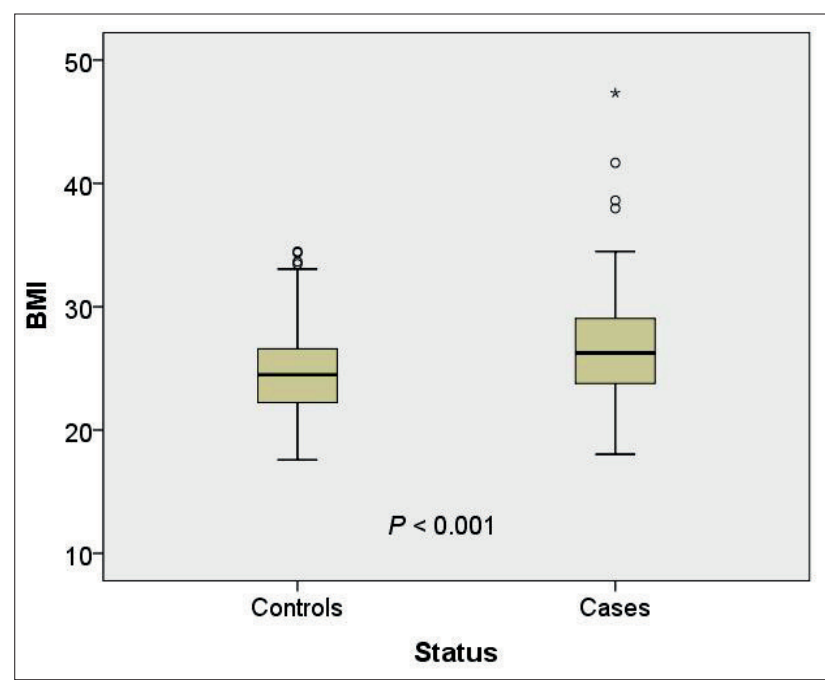

Fig. 2. Body mass index in psoriatic patients and controls.

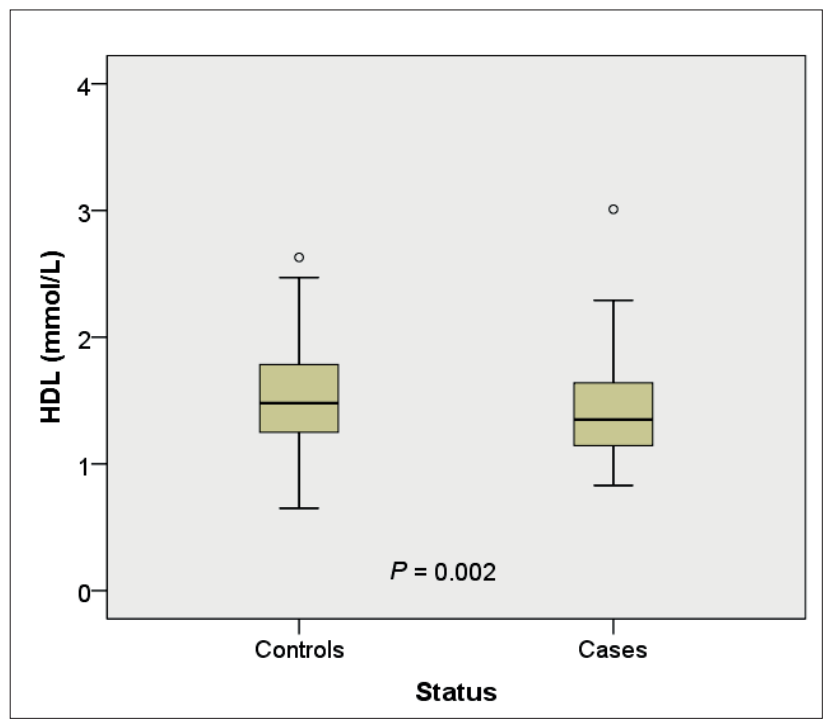

Fig. 4. High density lipoprotein concentrations in psoriatic patients and controls. 


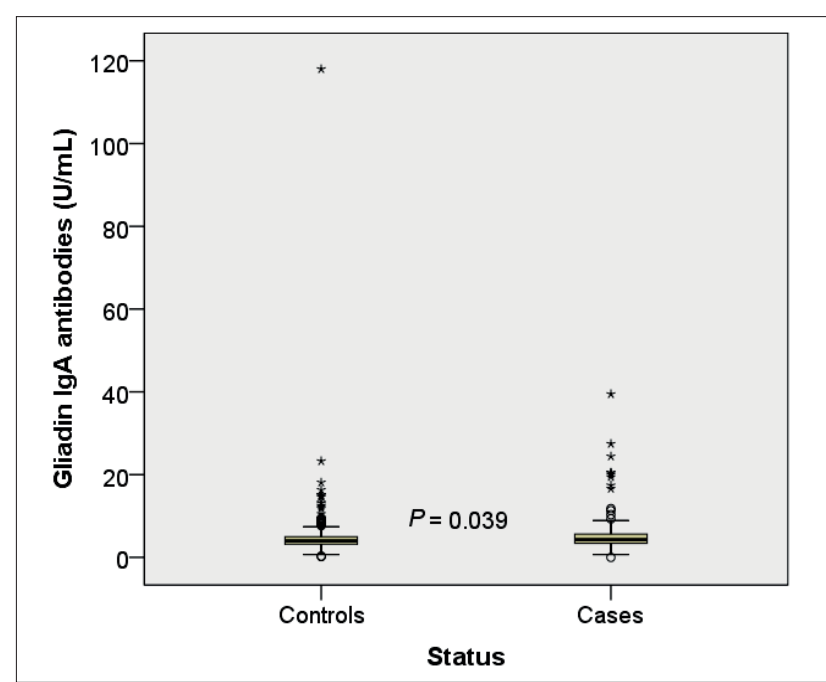

Fig. 5. Gliadin IgA antibodies in psoriatic patients and controls.

higher blood pressure than the control population is consistent with other published studies ${ }^{17,18}$.

Significant differences in lipidograms of psoriatic patients and a control population are statistically important only in levels of HDL cholesterol, which is decreased in patients with psoriasis. We consider this finding to be important because the association between psoriasis and this parameter is very robust, given the evidence from the multivariate model. In addition to lower levels of HDL, other studies report elevated total cholesterol levels in psoriasis ${ }^{19-21}$ and raised LDL and very low density lipoprotein (VLDL) cholesterol ${ }^{19-23}$. In this study, we also observed higher total cholesterol, LDL cholesterol and triacylglycerols. However, the differences between cases and controls were small and did not reach statistical significance.

Elevated baseline concentrations of CRP are associated with an increased risk of atherosclerotic events and serve as a predictive parameter both in primary and secondary prevention ${ }^{24}$. In this study, the increased levels of CRP in cases are borderline statistically significant $(P=0.066)$.

BMI values as a sign of obesity in psoriatic patients is increased and achieves significance both at binary as well as at multivariate levels of analyses. The finding of higher BMI values correlates with the expectations and is consistent with previously published results ${ }^{25,26}$.

Antigliadin antibodies (AGA) are diagnostic markers of celiac disease and several studies have reported an association between psoriasis and AGA, with improvements seen in the severity of psoriasis in patients on a gluten-free $\operatorname{diet}^{27,28}$. Our results seem to imply an association between psoriasis and asymptomatic coeliac disease.

Higher values of leukocytes in patients with psoriasis may be interpreted as a non-specific indicator of gastrointestinal diseases. This fact should be interpreted with caution however, as psoriasis is an inflammatory disease, and therefore the increased level of leukocytes may also be caused by skin disorders.

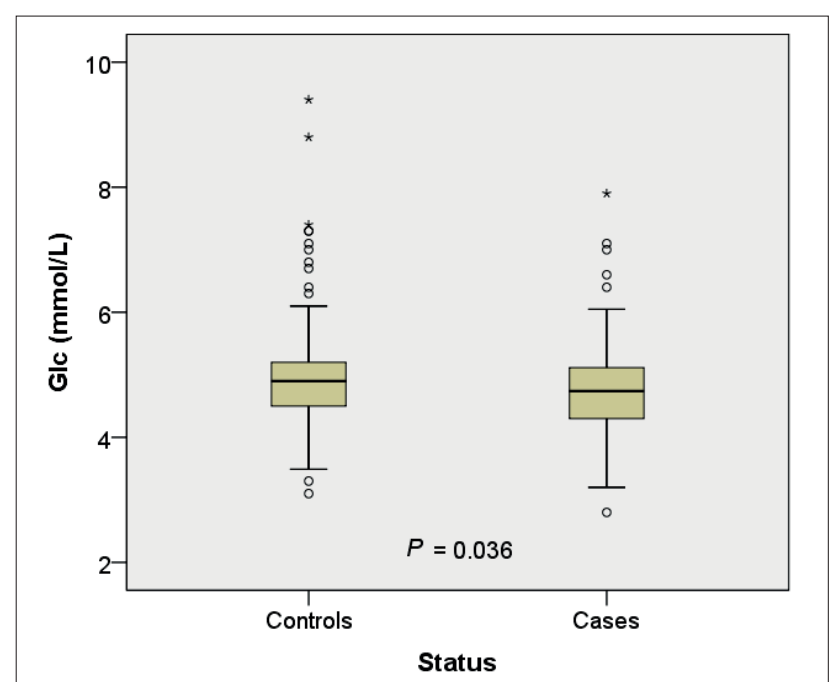

Fig. 6. Glycaemia in psoriatic patients and controls.

Despite the expectations arising from the published results of a number of studies ${ }^{18,29,30}$, a higher level of glycemia was not found in patients with psoriasis in our study.

\section{CONCLUSION}

Relatively small differences between cases and controls in this study should be interpreted as a very conservative result, as selection criteria for entering the study decreased differences between cases and controls. Consequently it means that the differences between patients and controls are in fact bigger than described. The Bergson bias leads to distortion towards zero too, which is a consequence of a well-known fact that the hospital controls are often people with a number of risk factors. The results of a study conducted on Czech patients with psoriasis suggest that detection of elevated or pathological values in several investigated parameters reached levels of statistical significance. Therefore, a regular screening of patients with chronic stationary form of psoriasis should become a standard for dermatologists in cooperation with general practitioners. An early diagnostics of these diseases and risk factors greatly improves the future quality of life of the patient and, last but not least, the early treatment of comorbidities reduces the cost of treating complications of these diseases. It is also necessary to ensure the awareness of psoriatic patients about possible associated diseases and increase the patients' awareness that a healthy lifestyle may prevent the development of certain comorbidities.

Dispensary care of patients suffering from psoriasis vulgaris should focus on primary and secondary prevention of diseases, to which it creates a predisposition. 


\section{ACKNOWLEDGEMENT}

The project was supported by the Charles University Grant Agency (Grant NO 110410) and the Internal Grant Agency of the Ministry of Health of the Czech Republic (Grant NT 13275/4).

\section{CONFLICT OF INTEREST STATEMENT}

None declared.

\section{REFERENCES}

1. Neimann AL, Shin DB, Wang X, Margolis DJ, Troxel AB, Gelfand JM. Prevalence of cardiovascular risk factors in patients with psoriasis. J Am Acad Dermatol 2006;55:829-35.

2. Gisondi P, Tessari G, Conti A, Piaserico S, Schianchi S, Peserico A, Giannetti A, Girolomoni G. Prevalence of metabolic syndrome in patients with psoriasis: a hospital-based case-control study. $\mathrm{Br}$ Dermatol 2007;157:68-73.

3. Kimball AB, Gladman D, Gelfand JM, Gordon K, Horn EJ, Korman NJ, Korver G, Krueger GG, Strober BE, Lebwohl MG. National Psoriasis Foundation clinical consensus on psoriasis comorbidities and recommendations for screening. J Am Acad Dermatol 2008;58:1031-42.

4. Warnecke C, Manousaridis I, Herr R, Terris DD, Goebeler M, Goerdt $\mathrm{S}$, Peitsch WK. Cardiovascular and metabolic risk profile in German patients with moderate and severe psoriasis: a case control study. Eur J Dermatol 2011;21(5):761-70.

5. Gelfand JM, Mehta NN, Langan SM. Psoriasis and cardiovascular risk: strength in numbers, part II., J Invest Dermatol 2011;131(5):1007-10. doi:10.1038/jid.2011.32

6. Gottlieb AB, Dann F, Menter A. Psoriasis and the metabolic syndrome. J Drugs Dermatol 2008;7(6):563-72.

7. Azfar RS, Gelfand JM. Psoriasis and metabolic disease: epidemiology and pathophysiology. Curr Opin Rheumatol 2008;20(4):416-2.

8. Mallbris L, Akre O, Granath F, Yin L, Lindelöf B, Ekbom A, StåhleBäckdahl M. Increased risk for cardiovascular mortality in psoriasis inpatients but not in outpatients. Eur J Epidemiol 2004;19:225-30.

9. Parimalam K, Jayakar T. Comorbid conditions in psoriasis - Higher frequency in females: A prospective study. Indian Dermatol Online J 2012;3(2):105-8.

10. Balci DD, Balci A, Karazincir S, Ucar E, Iyigun U, Yalcin F, Seyfeli E, Inandi T, Egilmez E. Increased carotid artery intima-media thickness and impaired endothelial function in psoriasis. J Eur Acad Dermatol Venereol 2009;23(1):1-6.

11. Einarsdottir E, Koskinen LL, Dukes E, Kainu K, Suomela S, Lappalainen M, Ziberna F, Korponay-Szabo IR, Kurppa K, Kaukinen K, Adány R, Pocsai Z, Széles G, Färkkilä M, Turunen U, Halme L, Paavola-Sakki P, Not T, Vatta S, Ventura A, Löfberg R, Torkvist L, Bresso F, Halfvarson J, Mäki M, Kontula K, Saarialho-Kere U, Kere J, D'Amato M, Saavalainen P. IL23R in the Swedish, Finnish, Hungarian and Italian populations: association with IBD and psoriasis, and linkage to celiac disease. BMC Med Genet 2009;28;10:8.
12. Stepanek J. Bezlepkova dieta v lecbe celiakie a psoriazy. Cas lek ces 2009;148(2):94-8

13. Blauvelt A. New concepts in the pathogenesis and treatment of psoriasis: key roles for IL-23, IL-17A and TGF- $\beta$. Expert Rev Dermatol 2007;2:69-78.

14. Pietrzak A, Jastrzębska I, Chodorowska G, Maciejewski R, Mosiewicz J, Krupski W, Prystupa A, Szubstarski F, Szepietowski JC, Hercogova J. Psoriasis and unreported excessive alcohol intake-a simple screening approach. J Eur Acad Dermatol Venereol 2011;25(11):1261-8.

15. Gelfand JM, Dommasch ED, Shin DB, Azfar RS, Kurd SK, Wang X, Troxel AB. The risk of stroke in patients with psoriasis. J Invest Dermatol 2009;129:2411-8.

16. Gelfand J, Neimann A, Shin D, Wang X, Margolis D, Troxel A. Risk of myocardial infarction in patients with psoriasis. JAMA 2006;296:1735-41.

17. Armstrong AW, Harskamp CT, Armstrong EJ. The association between psoriasis and hypertension: a systematic review and metaanalysis of observational studies. 2013;31(3):433-43. doi: 10.1097/ $\mathrm{HJH}$

18. Tseng HW, Lin HS, Lam HC. Co-morbidities in psoriasis: a hospitalbased case-control study. J Eur Acad Dermatol Venereol 2012;8. doi: 10.1111/jdv.12028

19. Mallbris L, Granath F, Hamsten A, Ståhle M.Psoriasis is associated with lipid abnormalities at the onset of skin disease. J Am Acad Dermatol 2006;54:614-21.

20. Akhyani M, Ehsani AH, Robati RM, Robati AM. The lipid profile in psoriasis: a controlled study. J Eur Acad Dermatol Venereol 2007; 21:1330-2.

21. Tekin NS, Tekin IO, Barut F, Sipahi EY.Accumulation of oxidized lowdensity lipoprotein in psoriatic skin and changes of plasma lipid levels in psoriatic patients. Mediators Inflamm 2007;2007:78454.

22. Gottlieb AB, Dann F. Comorbidities in patients with psoriasis. Am J Med 2009;122:1150 e1-9.

23. Pietrzak A, Michalak-Stoma A, Chodorowska G, Szepietowski JC. Lipid disturbances in psoriasis: an update.Mediators Inflamm 2010;2010.

24. Calabro P, Golia E, Yeh E.T. CRP and the risk of atherosclerotic events. Semin Immunopathol 2009;31:79-94.

25. Herron MD, Hinckley M, Hoffman MS, Papenfuss J, Hansen CB, Callis KP, Krueger GG. Impact of obesity and smoking on psoriasis presentation and management. Arch Dermatol 2005;141:1527-34

26. Bremmer S, Van Voorhees AS, Hsu S, Korman NJ, Lebwohl MG, Young M, Bebo BF Jr, Blauvelt A.Obesity and psoriasis: From the Medical Board of the National Psoriasis Foundation. J Am Acad Dermatol 2010;63:1058-69.

27. Nagui N, El Nabarawy E, Mahgoub D, Mashaly HM, Saad NE, El-Deeb DF. Estimation of $(\lg A)$ anti-gliadin, anti-endomysium and tissue transglutaminase in the serum of patients with psoriasis. Clin Exp Dermatol 2011;36(3):302-4.

28. Damasiewicz-Bodzek A, Wielkoszyński T. Serologic markers of celiac disease in psoriatic patients. J Eur Acad Dermatol Venereol 2008;22(9):1055-61.

29. Langan SM, Seminara NM, Shin DB, Troxel AB, Kimmel SE, Mehta NN, Margolis DJ, Gelfand JM. Prevalence of metabolic syndrome in patients with psoriasis: a population-based study in the United Kingdom. J Invest Dermatol 2012;132(3 Pt 1):556-62.

30. Madanagobalane $S$, Anandan S. Prevalence of metabolic syndrome in South Ind ian patients with psoriasis vulgaris and the relation between disease severity and metabolic syndrome: a hospital-based case-control study. Indian J Dermatol 2012;57(5):353-7. 